\title{
Modulation of platelet functions by crude rice (Oryza sativa) bran policosanol extract

Wai-Teng Wong ${ }^{1}$, Maznah Ismail ${ }^{1,2^{*}}$, Mustapha Umar Imam ${ }^{3^{*}}$ and Yi-Da Zhang ${ }^{4}$

\begin{abstract}
Background: Rice bran is bioactive-rich and has proven health benefits for humans. Moreover, its source, the brown rice has antioxidant, hypolipidemic and other functional properties that are increasingly making it a nutritional staple especially in Asian countries. This study investigated the antiplatelet aggregation mechanisms of crude hexane/methanolic rice bran extract, in which policosanol was the targeted bioactive. Platelets play a vital role in pathogenesis of atherosclerosis and cardiovascular diseases, and their increased activities could potentially cause arterial thrombus formation or severe bleeding disorders. Thus, in this study, platelet aggregation and adhesion of platelets to major components of basal lamina were examined in vitro. In addition, cellular protein secretion was quantified as a measurement of platelet activation.

Methods: Adenosine diphosphate (ADP), collagen, and arachidonic acid (AA)-induced aggregation were studied using the microtiter technique. Rat platelets were pre-treated with various concentrations of policosanol extract, and the adhesion of platelets onto collagen- and laminin-coated surface (extracellular matrix) was studied using the acid phosphatase assay. The effect of crude policosanol extract on released proteins from activated platelets was measured using modified Lowry determination method.

Results: Rice bran policosanol extract significantly inhibited in vitro platelet aggregation induced by different agonists in a dose dependent manner. The I $\mathrm{C}_{50}$ of ADP-, collagen-, and AA-induced platelet aggregation were $533.37 \pm 112.16,635.94 \pm$ 78.45 and $693.86 \pm 70.57 \mu \mathrm{g} / \mathrm{mL}$, respectively. The present study showed that crude rice bran policosanol extract significantly inhibited platelet adhesion to collagen in a dose dependent manner. Conversely, at a low concentration of 15. $625 \mu \mathrm{g} / \mathrm{mL}$, the extract significantly inhibited platelet adhesion to laminin stimulated by different platelet agonists. In addition to the alteration of cell adhesive properties, cellular protein secretion of the treated platelets towards different stimulants were decreased upon crude extract treatment.
\end{abstract}

Conclusion: Our results showed that crude rice bran policosanol extract could inhibit in vitro platelet adhesion, aggregation and secretion upon activation using agonists. These findings serve as a scientific platform to further explore alternative therapies in cardiovascular diseases related to platelet malfunction.

Keywords: Arachidonic acid, Adenosine diphosphate, Collagen, Platelet aggregation, Platelet adhesion, Laminin, Protein secretion

\section{Background}

The platelet is the smallest blood cell, which plays a major role in the occurrence of thrombosis, and to a greater extent, cardiovascular diseases. Stroke and coronary artery diseases are partly attributed to improper platelet activation [1]. Hyperlipidemia, diabetes, hypertension, poor dietary

\footnotetext{
*Correspondence: maznahis@upm.edu.my; mustyimam@gmail.com ${ }^{1}$ Laboratory of Molecular Biomedicine, Institute of Bioscience, Universiti Putra Malaysia, 43400 Serdang, Selangor, Malaysia

${ }^{3}$ Precision Nutrition Innovation Institute, College of Public Health, Zhengzhou University, Zhengzhou 450001, Henan Province, China

Full list of author information is available at the end of the article
}

and living patterns, as well as genetic inheritance are factors that promote platelet hyperactivity [2-5]. The critical balance of pro-coagulants and anti-coagulants in biological systems is crucial in preventing haemostatic complications [6]. Platelet activation sets in motion a cascade of events initiated by adhesion to exposed endothelial tissue (attachment to basal lamina), morphologic changes (expression of surface glycoproteins), cellular secretion (dense and alpha granule contents), and finally platelet aggregation. These eventually result in development of strong thrombus and 
atherosclerotic plaques through platelet-leucocytes interaction $[7,8]$.

Regulation of platelet functions using pharmacological agents or drugs such as aspirin, clopidogrel, or ticlopidine is an effective approach for the prevention of thrombotic plaques and atherosclerosis [9]. However, in recent decades, public perception on diet is changing, with an increasing number of people believing that natural foods that contain bioactive constituents could possibly diminish the risk factors of cardiovascular continuum [10-13]. Bioactives present in different fruits and vegetables are reported to be useful and good candidates as antiplatelet agents from natural-based or herbbased products as alternatives to commercial antiplatelet drugs [14-16].

Rice bran, a valuable source of food bioactives, is under-valued and under-utilized for applications until now [17]. Rice bran contains essential fatty acids, proteins, dietary fibers, vitamins, oil and other constituents, and is long believed to have health benefits particularly in cardiovascular diseases [18]. Rice bran is reported to have cholesterol-lowering properties in hypercholesterolemic hamsters and humans $[19,20]$. In addition to that, rice bran was shown promisingly to have blood glucoselowering, chemo-preventive and anti-aging properties [21-23]. Policosanols, which are long chain aliphatic fatty alcohols, are well acknowledged for their positive influence in pathophysiology. Previous studies had shown that sugarcane policosanol inhibited platelet aggregation by reducing serum thromboxane $\mathrm{A}_{2}$ yet increasing prostacyclin levels in rodents [24-26]. Furthermore, $200 \mathrm{mg} / \mathrm{kg}$ of sugarcane policosanol treatment significantly protected Mongolian gerbils from ligated carotid artery-induced cerebral ischemia, and this was also suggested to be a result of reduction in serum thromboxane $\mathrm{A}_{2}$ levels and increment in prostacyclin [27]. D-003, long chain aliphatic fatty acids which are structurally and metabolically closely related to the corresponding fatty alcohols, was shown to inhibit ex vivo collagen and adenoside diphosphate- (ADP-) induced aggregation effectively in rats. The mechanisms could be associated with prostaglandin synthesis and the protective effect against lipid peroxidation $[28,29]$.

Taking into account the above-mentioned, the present study was undertaken to determine the antiplatelet function of crude rice bran policosanol extract as there was no clear cut information on the mechanisms of action of rice bran policosanol although antiplatelet effects of other rice bran extracts were reported [30-32]. According to Cicero and Derosa [33], unlike other sources of policosanol, there are no studies currently demonstrating the antiplatelet effects of rice bran-derived policosanol. In regards, this paper described the effects of crude rice bran hexane/methanolic extract on rat platelet functions covering platelet adhesion to different coated surfaces, granular protein secretion and platelet aggregation towards different platelet activators.

\section{Methods \\ Materials}

Laminin, bovine serum albumin (BSA), p-nitrophenyl phosphate, and Triton X-100 were purchased from Merck (Darmstadt, Germany). Type I rat tail collagen was purchased from Sigma Aldrich Co. (St. Louis, MO, USA). Arachidonic acid (AA), equine tendon collagen, and ADP were purchased from Chrono-log Corp (Havertown, PA, USA). All other reagents were of analytical grade and were provided by commercial suppliers.

\section{Analytical procedures Plant materials}

Rice bran was obtained from Bernas milling factory in Kuala Selangor, Selangor, Malaysia. Rice bran sample with size of $4 \mathrm{~mm}$ was stabilized by heat treatment using an automated microwave oven (Microwave conditions: $2450 \mathrm{MHz}, 550 \mathrm{~W}, 110{ }^{\circ} \mathrm{C}, 200 \mathrm{~s}$ ). The sample was stored in $4{ }^{\circ} \mathrm{C}$ during the whole analysis.

\section{Extraction}

Policosanol was extracted using solid-liquid extraction according to the described procedures with minor modifications [34]. Briefly, $10 \mathrm{~g}$ of rice bran were placed in glass flask with approximately $150 \mathrm{~mL}$ of a mixture of hexane and methanol $(20: 1 \mathrm{v} / \mathrm{v})$. Extraction was performed by sonication technology $\left(50 \mathrm{~Hz}, 350 \mathrm{~W}, 50{ }^{\circ} \mathrm{C}\right.$, 3 h) using Power Sonic 505 ultrasonicator (Hwashin Technology Co., Seoul, Korea). The rice bran residues were removed from the solvent extract by centrifuging at $4000 \mathrm{rpm}$ for $10 \mathrm{~min}$. The solvent was completely removed from the extract using a rotary-evaporator under vacuum at $40{ }^{\circ} \mathrm{C}$ leading to greenish-yellow extract.

\section{GCMS analysis of policosanol extract}

The fatty alcohol was transformed into trimethylsilyl ethers using N, O-Bis (trimethylsilyl) trifluoroacetamide. The samples and standards were derivatized by incubating at $60{ }^{\circ} \mathrm{C}$ for $20 \mathrm{~min}$ and subsequently analyzed using gas chromatography mass spectrophotometry (TSQ series; Thermo Scientific, Waltham, MA, USA). Determination of policosanol content was done according to the method described by Ishaka et al. [35] with minor modifications. Standard mixture was prepared using chloroform, and $500 \mu \mathrm{L}$ of this mixture was derivatized with $200 \mu \mathrm{L}$ of derivatizing agent, after which the volume was made up to $1 \mathrm{~mL}$ by chloroform after cooling to room temperature. The GC oven temperature was programmed from 150 to $300{ }^{\circ} \mathrm{C}$ with a heating rate of $4{ }^{\circ} \mathrm{C} / \mathrm{min}$ and maintained at this temperature for $15 \mathrm{~min}$. 
Initial flow rate of the carrier gas, helium, was $1.0 \mathrm{~mL} /$ min, while the inlet temperature was $300{ }^{\circ} \mathrm{C}$. GC-MS parameters were as follows: the MS transfer line temperature was $280^{\circ} \mathrm{C}$, the ion source was kept at $230{ }^{\circ} \mathrm{C}$, and the MS quadrupole temperature was kept at $150{ }^{\circ} \mathrm{C}$. The ionization energy was $70 \mathrm{eV}$ with 2 scans/s and a mass range of 100-1000 amu. The standards/samples $(2 \mu \mathrm{L})$ were injected into GC-MS with a 1:10 split ratio.

\section{Ethics approval and animal handling}

Rat blood was obtained from Sprague-Dawley species with the ethical approval from institutional animal care and use committee (IACUC), Faculty of Medicine and Health Sciences, Universiti Putra Malaysia. Male rats were acclimatized at the animal house $\left(25-28{ }^{\circ} \mathrm{C}\right)$ for one week with ad libitum rodent chow and free access to clean pipe water.

\section{Blood platelet isolation}

Platelet isolation was performed according to the described procedures with minor modifications [36]. Blood was collected using tri-sodium citrated tubes $(109 \mathrm{mM}$ $3.2 \%$ ). Platelet rich plasma (PRP) was isolated by centrifugation at $100 \times \mathrm{g}$ for $20 \mathrm{~min}$. PRP was then centrifuged for additional $10 \mathrm{~min}$ at $1400 \times \mathrm{g}$ to sediment platelet pellet. The pellet was suspended in Tyrode HEPES buffer (134 mM NaCl, $2.9 \mathrm{mM} \mathrm{KCl}, 0.34 \mathrm{mM} \mathrm{Na} 2 \mathrm{HPO}_{4}, 12 \mathrm{mM}$ $\mathrm{NaHCO}_{3}, 20 \mathrm{mM}$ HEPES and $5 \mathrm{mM}$ glucose, $\mathrm{pH}$ 7.3), and washed twice to remove other cellular debris. Prostacyclin $(50 \mathrm{ng} / \mathrm{mL})$ was added during platelet isolation and washing steps. The platelets were suspended in Tyrode HEPES buffer at a final concentration of $10^{9}$ cells $/ \mathrm{mL}$.

\section{Platelet aggregation assay}

Platelet aggregation was studied using microtiter plate according to the described procedures with minor modifications [37]. Policosanol extract was dissolved in DMSO prior to all tests. Then, $100 \mu \mathrm{L}$ of platelet suspension pretreated with extract (extract final concentration 125$1000 \mu \mathrm{g} / \mathrm{mL}$, incubated for $10 \mathrm{~min}$ ) was pipetted into 96 well plates. Agonists were added to the wells accordingly (final concentration of ADP, collagen, and AA was $10 \mu \mathrm{M}$, $5 \mu \mathrm{g} / \mathrm{mL}$, and $0.5 \mathrm{mM}$ respectively). Double orbital shaking mode was used and the optical density at $405 \mathrm{~nm}$ was read every one min for 20 min using BioTeK Synergy H1 Hybrid Reader (BioTek Instruments Inc., Winooski, VT, USA). Platelet aggregation was calculated by subtracting the final reading from the initial reading of the same well followed by normalization with the DMSO control.

\section{Platelet adhesion assay}

Adhesion of platelets to laminin and collagen was determined according to the described procedures with minor modifications [38, 39]. Platelets were pre-incubated with policosanol extract at various concentrations (10 $\mathrm{min}$ at $37^{\circ} \mathrm{C}$ ) and DMSO served as vehicle control. Using a 96well plate, $50 \mu \mathrm{L}$ of $40 \mu \mathrm{g} / \mathrm{mL}$ of collagen $(0.05 \%$ in $\left.\mathrm{CH}_{3} \mathrm{COOH}\right)$ or $50 \mu \mathrm{L}$ of laminin solution $(1 \mathrm{mg} / \mathrm{mL}$ in phosphate buffer solution) was pre-incubated for $2 \mathrm{~h}$. The wells were subsequently treated with $200 \mu \mathrm{L}$ of PBS containing $1 \%$ BSA for $1 \mathrm{~h}$ after aspiration and washing with $200 \mu \mathrm{L}$ of PBS. AA $(0.5 \mathrm{mM})$, ADP $(10 \mu \mathrm{M})$, and collagen $(5 \mu \mathrm{g} / \mathrm{mL})$ were used as platelet activators, and incubated with $50 \mu \mathrm{L}$ of platelet suspension per each coated well at $37{ }^{\circ} \mathrm{C}$ for $1 \mathrm{~h}$. The plate was washed at least three times with $200 \mu \mathrm{L}$ PBS to remove unattached platelets. Subsequently, $140 \mu \mathrm{L}$ of the substrate solution containing $1 \mathrm{mg} / \mathrm{ml} p$-nitrophenyl phosphate in citrate buffer $(0.1 \mathrm{M}$ sodium citrate, $0.1 \mathrm{M}$ acetic acid and $0.1 \%$ (w/v) Triton X-100, pH 5.4) was added to each well. The reaction was stopped after $1 \mathrm{~h}$ incubation at $25{ }^{\circ} \mathrm{C}$ and the color was developed by addition of $100 \mu \mathrm{L}$ of $\mathrm{NaOH}(2 \mathrm{~N})$. The absorbance of the reaction product, $p$-nitrophenol, was measured at $405 \mathrm{~nm}$ using BioTeK Synergy H1 Hybrid Reader (BioTek Instruments Inc., Winooski, VT, USA).

\section{Platelet acid phosphatase assay}

A calibration curve was used to relate the platelet numbers to their acid phosphatase activity. This was performed according to the described procedures [40]. For the estimation of the total platelet count, $50 \mu \mathrm{L}$ of PRP was used, and for blank, $50 \mu \mathrm{L}$ of platelet poor plasma (PPP) was used. Platelet suspensions containing known cell numbers were dispensed in uncoated wells and incubated for $60 \mathrm{~min}$ at $25{ }^{\circ} \mathrm{C}$ with substrate solution containing $1 \mathrm{mg} / \mathrm{ml} p$-nitrophenyl phosphate in citrate buffer (0.1 M sodium citrate, $0.1 \mathrm{M}$ acetic acid and $0.1 \%$ (w/v) Triton $\mathrm{X}-100, \mathrm{pH}$ 5.4). The reaction was stopped and the color was developed by addition of $100 \mu \mathrm{L}$ of $\mathrm{NaOH}(2 \mathrm{~N})$. Subsequently, the absorbance of the reaction product, $p$-nitrophenol, was measured at $405 \mathrm{~nm}$ using BioTeK Synergy H1 Hybrid Reader (BioTek Instruments Inc., Winooski, VT, USA). The constructed graph was used to determine the number of platelets attached to laminin- and collagen-coated plates.

\section{Protein secretion assay}

Platelet suspension was incubated with policosanol extract at various concentrations $(7.8125-1000 \mu \mathrm{g} / \mathrm{mL})$ for $60 \mathrm{~min}$ at $37^{\circ} \mathrm{C}$. A standard curve was constructed using BSA powder. One hundred microliters $(100 \mu \mathrm{L})$ of standards/samples were dispensed into wells and $200 \mu \mathrm{L}$ of Biuret reagent was added to each well and mixed thoroughly. Biuret reagent was prepared by mixing $0.5 \mathrm{~mL}$ of $1 \%$ cupric sulfate with $0.5 \mathrm{~mL}$ of $2 \%$ sodium potassium tartrate, followed by the addition of $50 \mathrm{~mL}$ of $2 \%$ sodium carbonate in $0.1 \mathrm{~N} \mathrm{NaOH}$. The mixture was 
incubated $\left(15 \mathrm{~min}, 25{ }^{\circ} \mathrm{C}\right)$ followed by the addition of $20 \mu \mathrm{L} 1.0 \mathrm{~N}$ Folin-Ciocalteu's reagent into each well. Color was allowed to develop for $30 \mathrm{~min}$ at room temperature and the absorbance measured at $650 \mathrm{~nm}$ with BioTeK Synergy H1 Hybrid Reader (BioTek Instruments Inc., Winooski, VT, USA) [41].

\section{Statistical analysis}

The data were analyzed using minitab 16 (Minitab Inc, State College, Pennsylvania, United States) by one-way analysis of variance (ANOVA) and presented as means \pm standard deviation (SD). The significant differences between groups were determined at $p<0.05$.

\section{Results and discussion}

The present study demonstrated the effect of rice bran policosanol extract (Oryza sativa) on platelet function.
From our unpublished data, policosanol content of the extract was reported as $877.99 \pm 110.11 \mathrm{mg} / 100 \mathrm{~g}$ extract. Figure 1 showed the optical density trend for 25 min recorded using BioTeK Synergy H1 Hybrid Reader (BioTek Instruments Inc., Winooski, VT, USA). The optical density decreased with time as individual platelet cells were increasing becoming fewer. Optical density value decreased upon agonist addition and degree of platelet aggregation was calculated using the absorbance difference.

The present study showed that rice bran policosanol extract exerted antiplatelet aggregation effect towards ADP, collagen and AA as depicted in Table 1. From the tabulated data, we successfully demonstrated that policosanol extract inhibited platelet aggregation in a dose dependent manner. It was shown to have the strongest inhibitory action towards ADP-induced platelet aggregation. Low dose

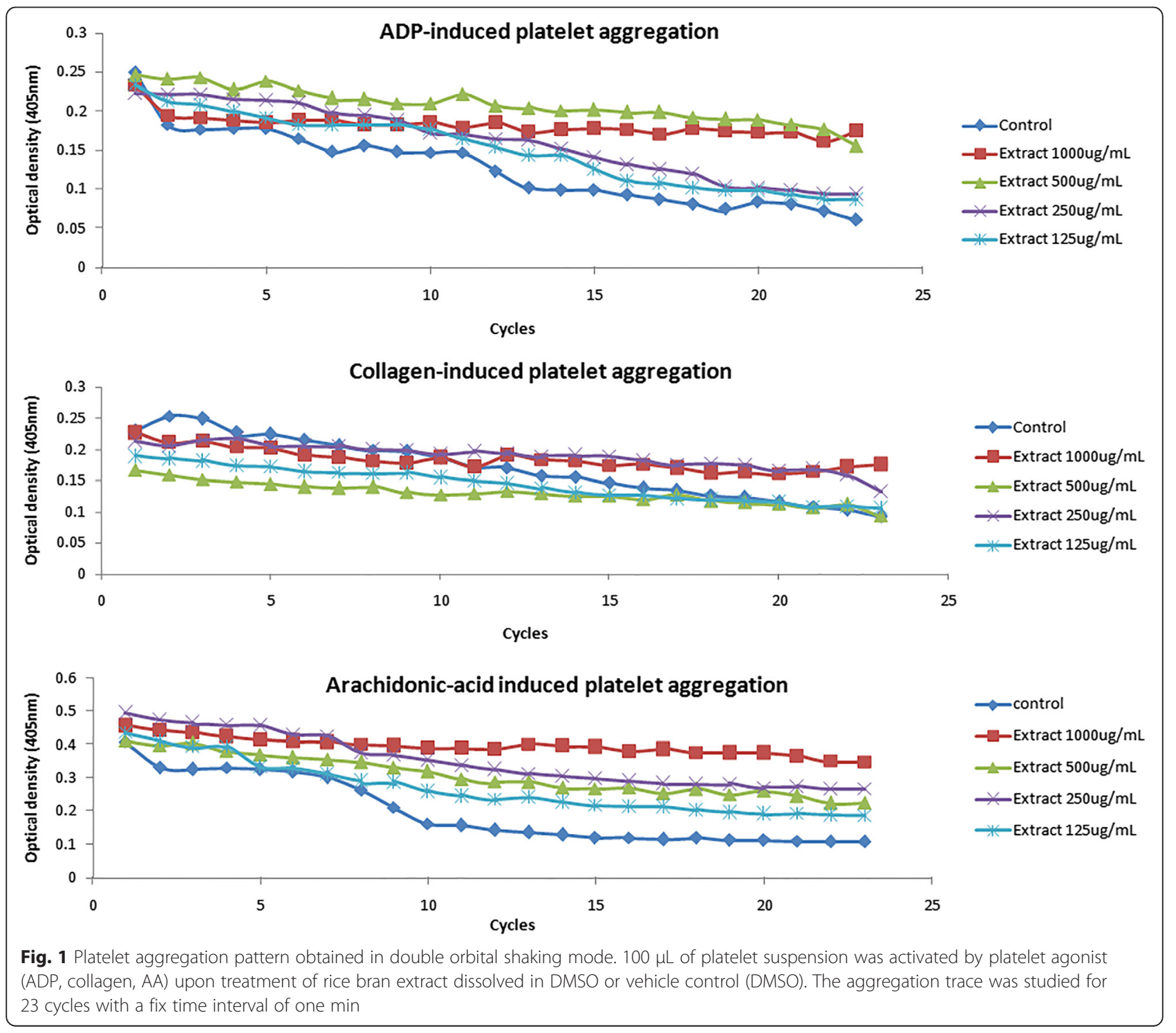


Table 1 Degree of platelet aggregation after treatment with extract

\begin{tabular}{llll}
\hline Extract $(\mu \mathrm{g} / \mathrm{mL})$ & \multicolumn{3}{l}{ Platelet aggregation $(\%)$ by different agonists } \\
\cline { 2 - 4 } & Adenosine diphosphate $(10 \mu \mathrm{M})$ & Collagen $(5 \mu \mathrm{g} / \mathrm{mL})$ & 100 \\
\hline 0 (control) & 100 & 100 & $34.75 \pm 4.27$ \\
1000 & $32.64 \pm 4.30$ & $38.00 \pm 5.85^{\mathrm{a}}$ & $60.58 \pm 3.68^{\mathrm{a}}$ \\
500 & $47.21 \pm 5.95^{\mathrm{a}}$ & $45.56 \pm 4.22^{\mathrm{a}}$ & $67.23 \pm 1.25^{\mathrm{a}, \mathrm{b}}$ \\
250 & $56.98 \pm 6.06^{\mathrm{a}}$ & $66.29 \pm 2.86^{\mathrm{b}}$ & $73.98 \pm 1.31^{\mathrm{b}}$ \\
125 & $73.61 \pm 4.50$ & $75.49 \pm 2.16^{\mathrm{b}}$ & $693.86 \pm 70.57$ \\
\hline$C_{50}(\mu \mathrm{g} / \mathrm{mL})$ & $533.37 \pm 112.16$ & $635.94 \pm 78.45$ & $0.5 \mathrm{mM})$ \\
\hline
\end{tabular}

The presented values were mean \pm standard deviation. Means that shared the same letter in any column were not significant different at $p<0.05$

rice bran extract $(125 \mu \mathrm{g} / \mathrm{mL})$ significantly inhibited platelet aggregation induced with ADP, collagen, and AA, while at $1000 \mu \mathrm{g} / \mathrm{mL}$, the extract significantly inhibited ADP, collagen, and AA-induced platelet aggregation by up to $67.36 \pm$ $4.30 \%, 62 \pm 5.85 \%$, and $65.25 \pm 4.27 \%$, respectively.

Furthermore, microscopic images of platelet aggregation are shown in Fig. 2. These observations again validated the antiplatelet effect of rice bran policosanol extract. The exact aggregation inhibitory mechanisms are yet to be known, although policosanol was shown to inhibit cyclooxygenase enzyme activity [42] and was reported to lower the production of serum thromboxane $[27,43]$. This explained why the extract used in the present study was able to inhibit AA-induced
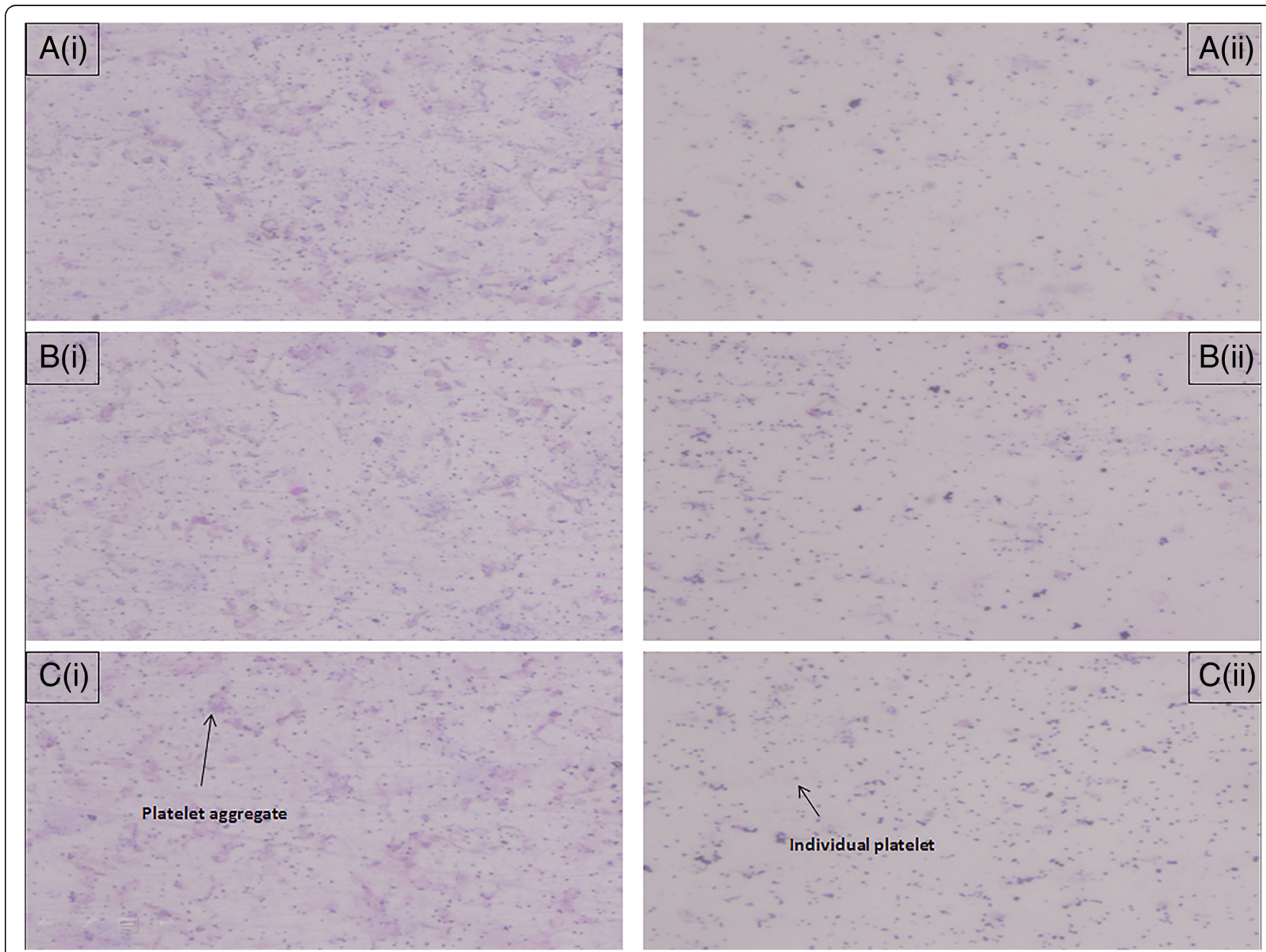

Fig. 2 Platelet was fixed with $0.5 \%$ formaldehyde after incubation with rice bran extracts. Smears were loaded on clean glass slide and covered with a cover glass. The samples were stained with Wright's stain and air dried before subjected to microscopic observation (Olympus, Japan). Platelet was activated by ADP, AA, and collagen $(\mathbf{a}, \mathbf{b}, \mathbf{c})$ upon treatment with (i) vehicle control (ii) rice bran extract $(500 \mu \mathrm{g} / \mathrm{mL})$ for $10 \mathrm{~min}$ at $37^{\circ} \mathrm{C}$ 


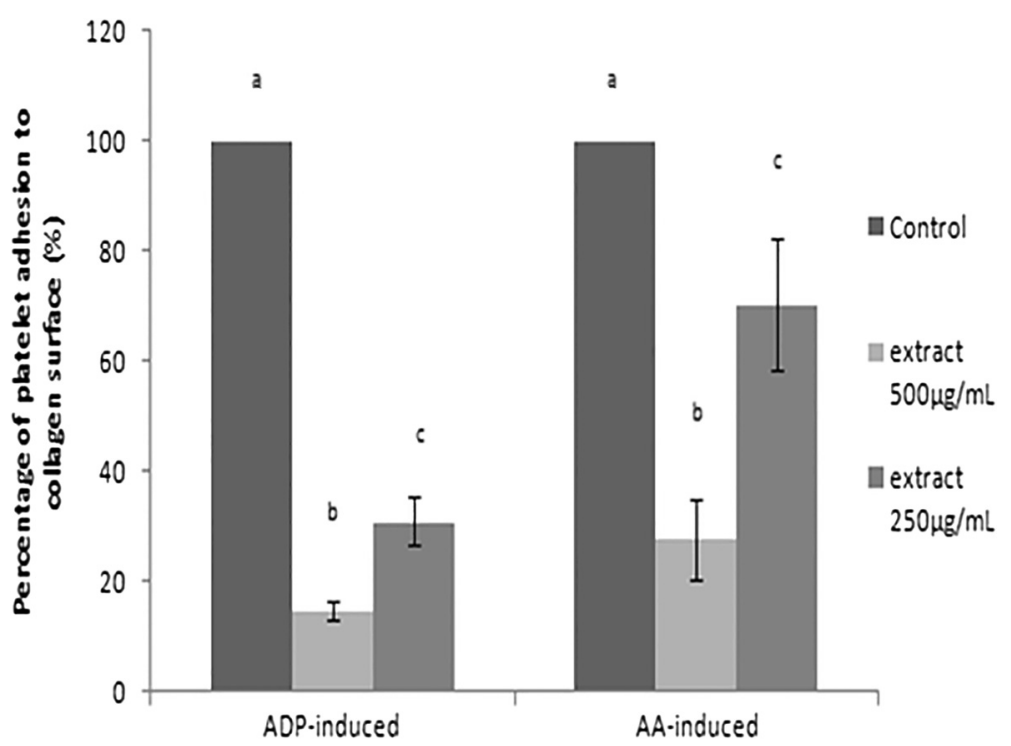

Fig. 3 Platelet adhesion onto collagen-coated surface upon extracts treatment (in percentage after normalized with vehicle control). Means that shared the same letter were not significantly different $(p<0.05)$

aggregation to a great extent. On the other hand, rice bran policosanol extract might enhance the production of cAMP by mediating adenylate cyclase activity via $\mathrm{G}_{\mathrm{i}^{-}}$ coupled $\mathrm{P}_{2} \mathrm{Y}_{12}$ receptor modulation [32]. Moreover, rice bran policosanol extract might also inhibit collageninduced platelet aggregation through direct binding to collagen, thus interfering with collagen-platelet interaction. Alternatively, rice bran extract may interact with the glycoprotein receptor, GPVI, to produce its effects. Reduced affinity of GPVI towards collagen attenuated thromboxane $\mathrm{A}_{2}$ synthesis through phospholipase $\mathrm{C}$ activity inhibition, and in addition, reduced degranulation and platelets recruitment $[44,45]$.

Platelet suspension was pre-incubated with different concentrations of policosanol extract and the adhesive property of platelets onto laminin or collagen surface was examined. The extent of adhesion was studied using acid phosphatase assay, as shown on Figs. 3 and 4. Policosanol extract was shown to inhibit platelet adhesion onto collagen surface in a dose dependent manner. The

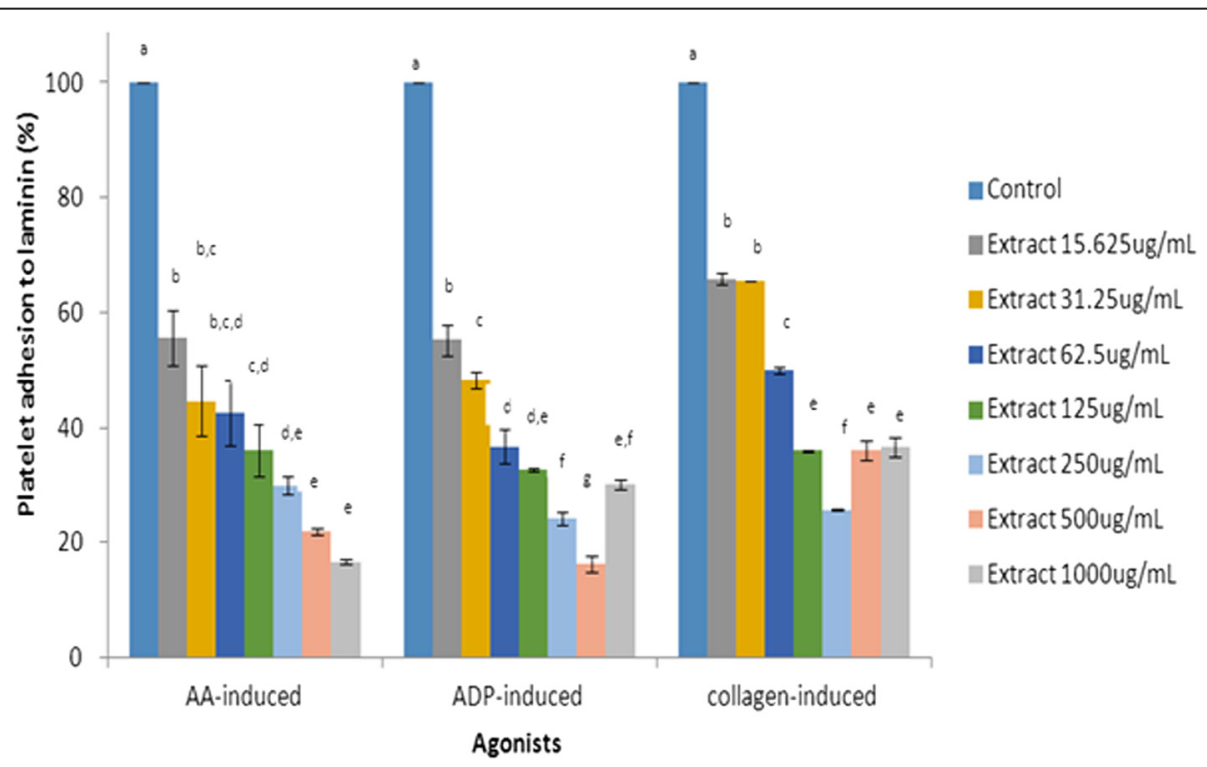

Fig. 4 Platelet adhesion onto laminin-coated surface upon extracts treatment (in percentage after normalized with vehicle control. Means that shared the same letter were not significantly different $(p<0.05)$ 
crude policosanol extract at a low concentration of $12.5 \mu \mathrm{g} / \mathrm{mL}$ significantly inhibited platelet adhesion. At a concentration of $500 \mu \mathrm{g} / \mathrm{mL}$, the extract significantly inhibited AA- and ADP-activated platelet adhesion by up to $72.32 \pm 7.14$ and $85.21 \pm 1.90 \%$, respectively, while at $1000 \mu \mathrm{g} / \mathrm{mL}$, it significantly inhibited AA-activated, ADP-activated and collagen-activated platelet adherence onto laminin surface by $83.39 \pm 0.46,69.86 \pm 0.73$ and $63.40 \pm 1.74 \%$, respectively. The results showed that at $500 \mu \mathrm{g} / \mathrm{mL}$, the extract was most effective in inhibiting ADP- and collagen-activated platelet adhesion to laminin, suggesting that it demonstrated a hormetic effect toward platelet adhesion whereby lower dosage was beneficial in certain responses, which is lost at higher dosages. Microscopic images of adhered platelets onto collagen-coated surface are shown in Fig. 5. The captured images provide semi-quantitative data in support of platelet modulation ability of policosanol extract. Compared to control depicted as Fig. 5a(i), policosanol extract significantly inhibited AA-activated platelets adhered onto collagen surface in a dose dependent manner. Likewise in Fig. 5b, the number of ADP-activated

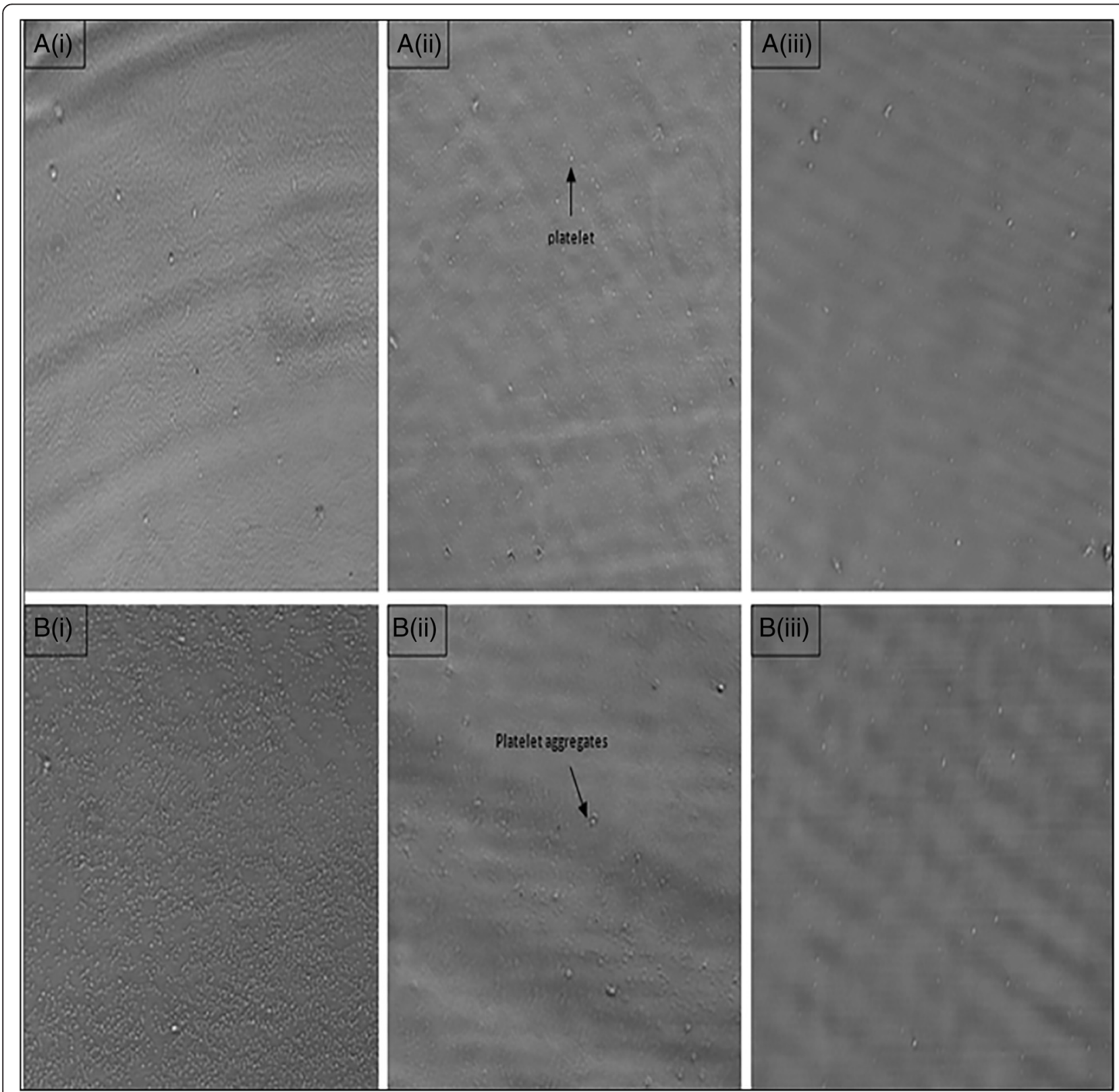

Fig. 5 Microscopic images of platelet adhesion. Wells were coated with collagen. Platelets were pre-incubated with policosanol extract and activated with (a) AA (b) ADP. (i) Platelets without extract (DMSO control) (ii) Platelets incubated with $250 \mathrm{\mu g} / \mathrm{mL}$ policosanol extract (iii) Platelets incubated with $500 \mathrm{\mu g} / \mathrm{mL}$ policosanol extract. The wells were loaded with PBS after washing and examined under inverted microscope ( $\times 10)$ 
platelets adhered onto collagen surface was attenuated upon extract treatment.

Crude rice bran policosanol extract might exert its aggregation inhibitory effect by targeting enzyme activities in the prostaglandin pathway. Impairment of prostaglandin synthesis pathway will reduce platelet adhesion, intracellular signaling and activation, and platelet-platelet interaction [46]. Policosanol extract could also possibly reduce the secretion of coagulating proteins, cell activating agents or adhesion molecules (e.g. platelet vWF, ADP) which are essential in platelet adhesion [37]. Figure 6 shows the attenuation of protein secreted from activated platelets. At a concentration of $500 \mu \mathrm{g} / \mathrm{mL}$, the extract significantly attenuated protein secretion from ADP- and AA-activated platelets. However, the extract produced better inhibition of collagen-induced granular protein secretion at $250 \mu \mathrm{g} / \mathrm{mL}$.

Glycoprotein expression is another possible target of policosanol action. Platelets possess receptors for various proteins such as collagen, fibronectin, fibrinogen, von Willebrand factor, laminin, thrombus protein and vitronectin [47]. Different responses of platelets towards different stimulants and compounds could imply inhibition of certain signaling molecules, pathways or specific receptors. Platelets bind to collagen directly or indirectly via GPIV, GPVI or GPIa/IIa, while their interaction with laminin is mediated by integrin GPIc/IIa (VLA-6) receptor [48]. Platelet studies have shown that initial platelet adhesion appears to be mediated by GPIIb/IIIa [49]. Any ligand binding or blockage to these glycoprotein receptors might probably inhibit platelet adhesion to collagen and laminin to a certain extent.

It is believed that policosanol extract can inhibit platelet hyperactivity through a multitude of mechanisms including scavenging of reactive oxygen species (ROS) [50]. Presence of other bioactive constituents in the crude extract, for instances, phenolics, aldehydes, or flavonoids might exert antioxidant ability synergistically, and thus prevent platelet adhesion. Signalling pathways during platelet activation, for instance metabolism of AA by COX and lipoxygenase, metabolism of phosphoinositide and glutathione cycle mediate intracellular ROS production [37]. Holistically, strong ROS scavenging ability can effectively attenuate platelet activation. To summarize, the present study provided a scientific basis to support consumption of rice bran in promoting good health, more specifically, in preventing cardiovascular diseases.

\section{Conclusion}

The present study demonstrated that crude rice bran policosanol extract effectively inhibited platelet aggregation and platelet adhesion onto laminin and collagen surfaces, and attenuated protein secretion from platelets

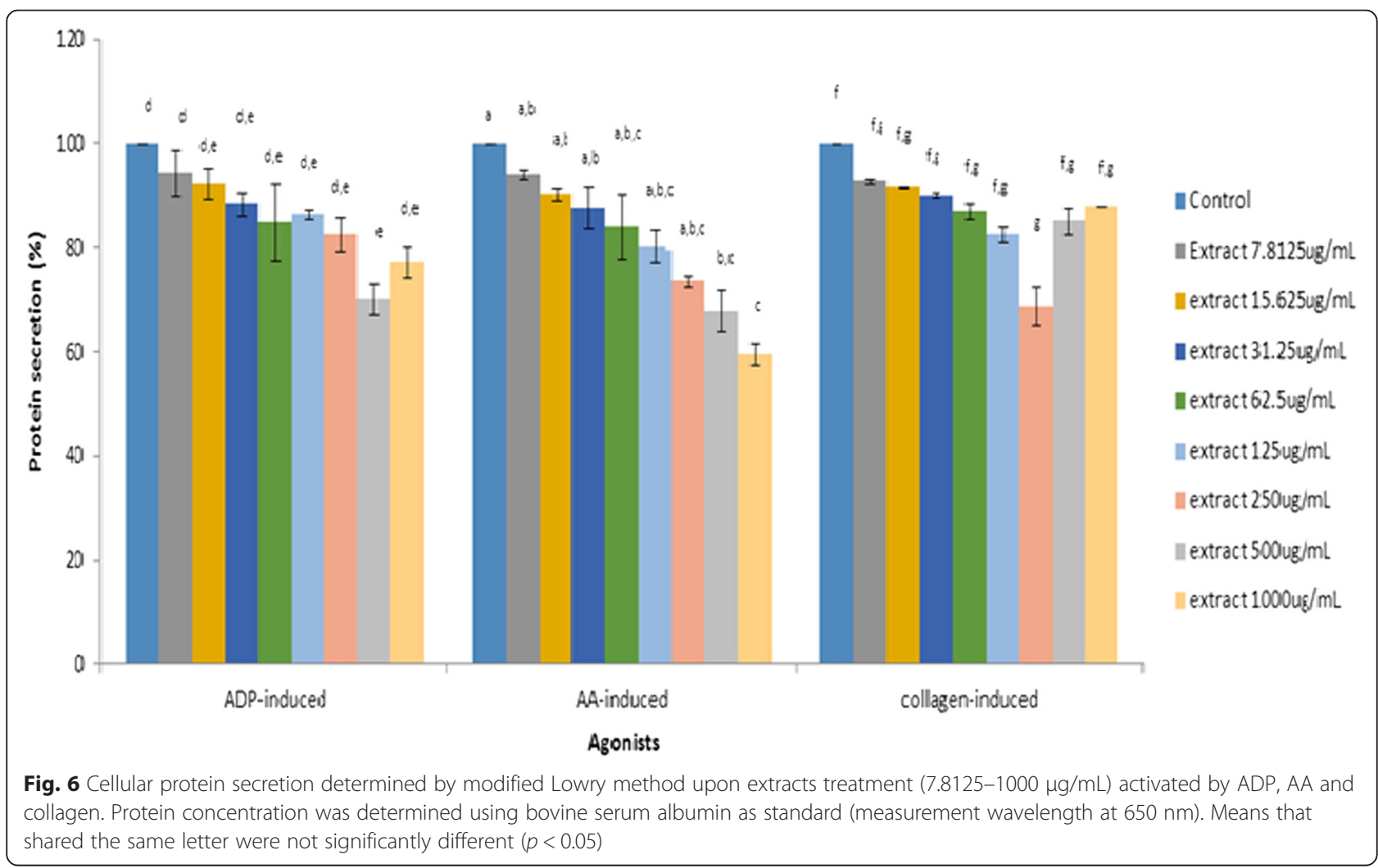


induced by different platelet activators. The present study provides further insights into the health value of rice bran. These findings serve as a scientific platform to further explore alternative therapies in cardiovascular diseases.

\section{Abbreviations}

AA, Arachidonic acid; ADP, Adenosine diphosphate; BSA, Bovine serum albumin; COX, Cyclooxygenase; PBS, Phosphate buffer solution; PRP, Platelet rich plasma; ROS, Reactive oxygen species; vWF, von Willebrand factor

\section{Acknowledgement}

The financial support from Ministry of Education Malaysia (Knowledge Transfer program-Project Number 6228130) is gratefully acknowledged. The authors thank Padiberas Nasional Berhad (Selangor, Malaysia) for providing rice milling by-product and the staff of Institute of Bioscience, Universiti Putra Malaysia for the kind assistance.

\section{Funding}

This project was funded by Ministry of Education Malaysia (Knowledge Transfer program-Project Number 6228130).

\section{Availability of data and materials}

The data that support the findings of this study are available from the corresponding authors on request.

\section{Authors' contributions}

WaiTeng-Wong (WWT) and Maznah Ismail (MI) conceived the project, and together with YiDa-Zhang (ZYD) conducted the experiments. WWT, ZYD and Mustapha Umar Imam (MUI) analyzed the data and drafted the content. All authors read, revised and approved the final manuscript. Ml gave the final approval of this version to be published.

\section{Competing interests}

The authors declare that they have no competing interests.

\section{Consent for publication}

Not applicable.

\section{Ethics approval and consent to participate}

Ethical approval was obtained from the institutional animal care and use committee (IACUC), Faculty of Medicine and Health Sciences, Universiti Putra Malaysia.

\section{Author details}

'Laboratory of Molecular Biomedicine, Institute of Bioscience, Universiti Putra Malaysia, 43400 Serdang, Selangor, Malaysia. ${ }^{2}$ Department of Nutrition and Dietetics, Faculty of Medicine and Health Sciences, Universiti Putra Malaysia, 43400 Serdang, Selangor, Malaysia. ${ }^{3}$ Precision Nutrition Innovation Institute, College of Public Health, Zhengzhou University, Zhengzhou 450001, Henan Province, China. ${ }^{4}$ Cardiology Department, Affiliated Hospital of Chengde Medical University, 067000 Chengde, Hebei, China.

\section{Received: 5 December 2015 Accepted: 15 July 2016}

\section{Published online: 28 July 2016}

\section{References}

1. Briere JB. Essential thrombocythemia. Orphanet J Rare Dis. 2007:2(3):1-17.

2. Sener A, Ozsavci D, Oba R, Demirel GY, Uras F, Yardimci KT. Do platelet apoptosis, activation, aggregation, lipid peroxidation and platelet-leukocyte aggregate formation occur simultaneously in hyperlipidemia? Clin Biochem. 2005;38(12):1081-7.

3. Kakouros N, Rade JJ, Kourliouros A, Resar JR. Platelet function in patients with diabetes mellitus: from a theoretical to a practical perspective. Int J Endocrinol. 2011.

4. Markel A, Brook JG, Levy Y, Aviram M, Youdim MB. Increased platelet adhesion and aggregation in hypertensive patients: effect of atenolol. $\mathrm{Br} \mathrm{J}$ Clin Pharmacol. 1983;16(6):663-8.
5. Nara Y, Kihara M, Nabika T, Mano M, Horie R, Yamori Y. Dietary effect on platelet aggregation in men with and without a family history of essentia hypertension. Hypertension. 1984;6(3):339-43.

6. Dahlbäck B. Blood coagulation and its regulation by anticoagulant pathways: genetic pathogenesis of bleeding and thrombotic diseases. J Intern Med. 2005:257(3):209-23.

7. Coppinger JA, Cagney G, Toomey S, Kislinger T, Belton O, McRedmond JP, Cahill DJ, Emili A, Fitzgerald DJ, Maguire PB. Characterization of the proteins released from activated platelets leads to localization of novel platelet proteins in human atherosclerotic lesions. Blood. 2004;103:2096-104

8. Yeh JJ, Tsai S, Wu DC, Wu JY, Liu TC, Chen A. P-selectin-dependent platelet aggregation and apoptosis may explain the decrease in platelet count during Helicobacter pylori infection. Blood. 2010;115(21):4247-53.

9. Hubbard GP, Stevens JM, Cicmil M, Sage T, Jordan PA, Williams CM, Lovegrove JA, Gibbins JM. Quercetin inhibits collagen stimulated platelet activation through inhibition of multiple compounds of the glycoprotein VI signaling pathway. J Thromb Haemost. 2003;1:1079-88.

10. Kerver J, Yang E, Bianchi L, Song W. Dietary patterns associated with risk factors for cardiovascular disease in healthy US adults. Am J Clin Nutr. 2003:78:1103-10.

11. Osganian S, Stampfer M, Rimm E, Spiegelman D, Manson J, Willet W. Dietary carotenoids and risk of coronary artery disease in women. Am J Clin Nutr. 2003;77:1390-9.

12. Dutta-Roy AK. Dietary components and human platelet activity. Platelets. 2002;13(2):67-75.

13. Rajaram $\mathrm{S}$. The effect of vegetarian diet, plant foods, and phytochemicals on hemostasis and thrombosis. Am J Clin Nutr. 2003;78:552-8.

14. Halliwell B. Lipid peroxidation, antioxidants and cardiovascular disease: how should we move forward? Cardiovasc Res. 2000;47(3):410-8.

15. Visioli F, Borsani L, Galli C. Diet and prevention of coronary heart disease: the potential role of phytochemicals. Cardiovasc Res. 2000;479(3):419-25.

16. Mekhfi H, Haouari ME, Legssyer A, Bnouham M, Aziz M, Atmani F, Remmal A, Ziyyat A. Platelet anti-aggregant property of some Moroccan medicinal plants. J Ethnopharmacol. 2004:94:317-22.

17. Shih FF. An update on the use of co-products from the milling of rice in value-added food products. J Am Oil Chem Soc. 2012:89(1):1-8.

18. Prasad MN, Sanjay KR, Shravya Khatokar M, Vismaya MN, Nanjunda Swamy S. Health Benefits of Rice Bran - A Review. J Nutr Food Sci. 2011:1:108.

19. Kahlon TS, Saunders RM, Sayre RN, Chow Fl, Chiu MM, Betschart AA. Cholesterol-lowering effects of rice bran and rice bran oil fractions in hypercholesterolemic hamsters. Cereal Chem. 1992;69:485.

20. Most MM, Tulley R, Morales S, Lefevre M. Rice bran oil, not fiber, lowers cholesterol in humans. Am J Clin Nutr. 2005:81(1):64-8.

21. Takakori Z, Zare M, Iranparvare M, Mehrabi Y. Effect of rice bran on blood glucose and serum lipid parameters in diabetes II patients. Internet J Nutr Wellness. 2004, 2(1):1-5.

22. Henderson AJ, Ollila CA, Kumar A, Borresen EC, Raina K, Agarwal R, Ryan EP. Chemopreventive properties of dietary rice bran: current status and future prospects. Adv Nutr. 2012:3(5):643-53.

23. Manosroi A, Chutoprapat R, Abe M, Manosroi W, Manosroi J. Anti-aging efficacy of topical formulations containing niosomes entrapped with rice bran bioactive compounds. Pharm Biol. 2012;50(2):208-24.

24. Arruzazabala ML, Carbajal D, Molina V, Valdés S, Más R, García M. Estudio farmacológico de la interacción del policosanol y la aspirina en animales de experimentación. Rev Iberoam Trombos Hemost. 1992:5:17-20.

25. Arruzazabala ML, Carbajal D, Más R, García M, Fraga V. Effect of policosanol on platelet aggregation in rats. Thromb Res. 1993;69:321-7.

26. Carbajal D, Arruzazabala ML, M'as R, Molina V, Valdes S. Effect of policosanol on experimental thrombosis models. Prostaglandins Leukot Essent Fatty Acids. 1994:50:249.

27. Arruzazabala ML, Carbajal D, Molina V, Valdés S, Más R. Effect of policosanol on cerebral ischemia in mongolian gerbils: Role of prostacyclin and thromboxane A2. Prostaglandins Leukot Essent Fatty Acids. 1993;49:695-7.

28. Molina V, Arruzazabala ML, Carbajal D, Más R, Valdés S. Antiplatelet and antithrombotic effect of D-003. Pharmacol Res. 2000;42(2):137-43.

29. Molina V, Arruzazabala ML, Carbaja D, Más R. Synergistic effect of D-003 and aspirin on experimental thrombosis models. Prostaglandins Leukot Essent Fatty Acids. 2003:68(5):305-10.

30. Maliki NZ. Effects of oryzanol and tocotrienol on platelet aggregation and blood lipid profile in rats. Master thesis, Universiti Putra Malaysia, Selangor Malaysia: Universiti Putra Malaysia; 2007 
31. Kim HH, Lee DH, Hong JH, Ingkasupart P, Nam GS, Ok WJ, Kim MJ, Yu YB, Kang $\mathrm{HC}$, Park HJ. Inhibitory effects of rice bran water extract fermented Lactobacillus plantarum due to CAMP-dependent phosphorylation of VASP (Ser157) on human platelet aggregation. Biomed Sci Lett. 2015;21(2):103-14.

32. Kim HH, Hong JH, Ingkasupart $\mathrm{P}$, Lee $\mathrm{DH}$, Park $\mathrm{HJ}$. Inhibitory effects of water extract from rice bran due to CAMP-dependent phosphorylation of VASP (Ser157) on ADP-induced platelet aggregation. Biomed Sci Lett. 2014;20(3):129-38.

33. Cicero AFG, Derosa G. Rice bran and its main components: potential role in the management of coronary risk factors. Curr Topics Nutraceutical Res. 2005;3(1):29-46.

34. Asikin Y, Takahashi M, Hirose N, Hou DX, Takara K, Wada K. Wax, policosanol, and long-chain aldehydes of different sugarcane (Saccharum officinarum L.) cultivars. Eur J Lipid Sci Technol. 2012;114(5):583-91.

35. Ishaka A, Imam MU, Mahamud R, Zuki ABZ, Maznah I. Characterization of rice bran wax policosanol and its nanoemulsion formulation. Int J Nanomedicine. 2014;9:2261.

36. Vaiyapuri S, Gibbins JM. Miniaturised platelet aggregation assays using Novostar microplate reader. BMG Labtech Appl Note 215, Rev. 04. 2011. http://www.bmglabtech.com/condeon/cdata/media/35216/1043890.pdf. Accessed 4 May 2015.

37. Moran N, Kiernan A, Dunne E, Edwards RJ, Shields DC, Kenny D. Monitoring modulators of platelet aggregation in a microtiter plate assay. Anal Biochem. 2006;357(1):77-84.

38. Yazdanparast R, Shahriyary L. Comparative effects of Artemisia dracunculus, Satureja hortensis and Origanum majorana on inhibition of blood platelet adhesion, aggregation and secretion. Vascul Pharmacol. 2008:48(1):32-7.

39. Olas B, Wachowicz B, Stochmal A, Oleszek W. Inhibition of blood platelet adhesion and secretion by different phenolics from Yucca schidigera Roezl. Bark Nutr. 2005;21:199-206.

40. Shahriyary L, Yazdanparast R. Inhibition of blood platelet adhesion, aggregation and secretion by Artemisia dracunculus leaves extracts. J Ethnopharmacol. 2007;114(2):194-8.

41. Lowry OH, Rosebrough NJ, Farr AL, Randall RJ. Protein measurement with the folin phenol reagent. J Biol Chem. 1951;193:265-75.

42. Pérez Y, Mas R, Oyarzábal A, Jiménez S, Molina V. Effects of policosanol (sugar cane wax alcohols) and D-003 (sugarcane wax acids) on cyclooxygenase (COX) enzyme activity in vitro. Int J Pharm Sci Rev Res. 2013;19(2):18-23.

43. Carbajal D, Arruzazabala MDL, Valdes S, Más R. Effect of policosanol on platelet aggregation and serum levels of arachidonic acid metabolites in healthy volunteers. Prostaglandins Leukot Essent Fatty Acids. 1998;58(1):61-4.

44. Farndale RW. Collagen-induced platelet activation. Blood Cells Mol Dis. 2006;36(2):162-5.

45. Yoshida S, Sudo T, Niimi M, Tao L, Sun B, Kambayashi J, Matsuoka H. Inhibition of collagen-induced platelet aggregation by anopheline antiplatelet protein, a saliva protein from a malaria vector mosquito. Blood. 2008;111(4):2007-14

46. Molina-Cuevas V, Carbajal-Quintana D, de Lourdes Arruzazabala-Valmaña M, Ravelo-Calzado Y, Mas-Ferreiro R. Comparative study of policosanol and grape seed extract on platelet aggregation in rats. Revista CENIC Ciencias Biológicas. 2011;42(1):3-6.

47. Bellavite P, Andrioli G, Guzzo P, Arigliano P, Chirumbolo S, Manzato F, Santonastaso C. A colorimetric method for the measurement of platelet adhesion in microtiter plates. Anal Biochem. 1994;216:444-50.

48. Tandon NN, Holland EA, Kralisz U, Kleinman HK, Robey FA, Jamieson GA. Interaction of human platelets with laminin and identification of the $67 \mathrm{kDa}$ laminin receptor on platelets. Biochem J. 1991;274:535-42.

49. Broberg M, Eriksson C, Nygren H. Gpllb/lla is the main receptor for initial platelet adhesion to glass and titanium surfaces in contact with whole blood. J Lab Clin Med. 2002;139(3):163-72.

50. Fraga V, Menéndez R, Amor AM, González RM, Jimenez S, Más R. Effect of policosanol on in vitro and in vivo rat liver microsomal lipid peroxidation. Arch Med Res. 1997;28:355-60.

\section{Submit your next manuscript to BioMed Central and we will help you at every step:}

- We accept pre-submission inquiries

- Our selector tool helps you to find the most relevant journal

- We provide round the clock customer support

- Convenient online submission

- Thorough peer review

- Inclusion in PubMed and all major indexing services

- Maximum visibility for your research

Submit your manuscript at www.biomedcentral.com/submit

C Biomed Central 